\title{
Which Perennial Crop Farm Approach Generates More Profitability? A Case Study in Dak Lak province, Vietnam
}

\author{
Phan Thi Thuy ${ }^{1,2}$, Thi Minh Hop $\mathrm{Ho}^{2}$, Philippe Burny ${ }^{2}$, Le Duc Niem ${ }^{1} \&$ Philippe Lebailly ${ }^{2}$ \\ ${ }^{1}$ Faculty of Economics, Tay Nguyen University, 567 Le Duan Street, Buon Ma Thuot, Vietnam \\ ${ }^{2}$ Economic and Rural Development, Gembloux Agro-Bio Tech, University Liège, Gembloux, Belgium \\ Correspondence: Phan Thi Thuy. Tel: 32-48-833-8637/+84-93-534-6969. E-mail: phanthuydhtn@gmail.com
}

Received: July 7, 2019 Accepted: July 22, $2019 \quad$ Online Published: August 30, 2019

doi:10.5539/ass.v15n9p1 URL: https://doi.org/10.5539/ass.v15n9p1

\begin{abstract}
Dak Lak Province, Vietnam has been identified as the optimal growing area region of cash crops. However, in recent years, perennial crops have faced some challenges need to have a new approach to maintain production sustainability. This study primarily provides a comparative analysis of the economic performance of crop cultivation by two approaches, mono-crop approaches including mono-coffee farms (MCFs) and mono-pepper farms (MPFs); intercropped approaches comprising intercropped coffee farms (ICFs) and intercropped pepper farms (IPFs). Additionally, this paper identifies the main factors affecting the farmer's adoption decision on different intercropped farm types. Based on an investigation of 120 selected farms, focus group discussions (FGDs) and participant assessments, from January to April 2019, the information about farming operations, costs and profits also were collected. The findings indicated that intercropped farms (include ICFs and IPFs) had a higher reduction of variable costs than mono-crop farms (MCFs and MPFs). Likewise, between two intercropped farm types, ICFs that wasted fewer input costs seem to be more appropriate for the poor and small saving households than that of IPFs. Moreover, ICFs and IPFs generate more profitability, increase by $62 \%$ and $25.7 \%$ as compared with MCFs and MPFs, respectively. Going forward, the study revealed factors influencing farmers' decision-making on applying different approaches for intercropped farms. These comprise farm profiles (pest and disease status; the age of the tree), farmers' characteristics (training) and economic factors (profits and other income). The findings devote information to intercropped farms in terms of enhancing economic benefits should be promoted for the coming years. Looking beyond, this empirical evidence is likely a useful contribution to farming management. What's more, the factors highlighted here demonstrate the need for continued improvement in such farming strategies.
\end{abstract}

Keywords: Perennial crop farms, profitability, Dak Lak province, coffee, pepper, Vietnam

\section{Introduction}

Currently, more than one-fourth of the land surface in the world has been shifted for agricultural land and more land is appropriate for annual as well as perennial crops growing (Godfray et al., 2010). In parallel, the enhance of agriculture in general and perennial crops, in particular, can contribute to economic growth, jobs creation, and poverty alleviation. Also, this brings important sources of income emphasized through recent empirical evidence (Godoy \& Bennett, 1991; Cuong, 2009; Romyen, Sausue, \& Charenjiratragul, 2018). Furthermore, the conversion to perennial crops deals with multiple issues involving environmental conservation and food security. On the other side, the perennial crop production seems to be more efficient (such as economic efficiency, soil erosion prevention, and habitat for wildlife) than annual crop one (Pimentel et al., 1987; Dinnes et al., 2002; Entz et al., 2002; Batello et al., 2014; Dixon \& Dennis, 2014). Subsequently, it is crucial to have a study of the perennial crop farms.

Ubiquitously, over the last few decades, Vietnam's agricultural sector has achieved impressive results such as poverty alleviation, national food security and social stability (World Bank, 2016). In other words, Vietnam has become one of the top five exporters for commodities like coffee, cashew, and pepper, in which coffee reached over 3 billion USD in 2018 (GSO, 2019). Thus, approximately 70\% of households' income is from perennial crops, in which $40 \%$ of those is from black pepper (NIAPP, 2017). However, over $90 \%$ of perennial crop households are in small scale (over $95 \%$ of coffee farms) and $75 \%$ of them has one hectare or less, sometimes, dispersed several plots (Scherr et al., 2015). 
Turning to Dak Lak Province that located in the Central Highlands has developed perennial crops early relying on the favorable endowment and the largest perennial crop-growing region. Apart from coffee, Dak Lak also grows other perennial crops like pepper, rubber, and cashew. Heretofore, the perennial crop sector has played a principal role in the provincial economy (i.e., the coffee growing area dominated $30 \%$ and $40 \%$ of the total national area and output in 2017) (GSO, 2018). It is evident that the perennial crops are the economic trees and the main sources of rural household income in this Dak Lak Province (Nguyen, 2017). Moreover, intercropped farms between coffee and pepper that developed rapidly in Dak Lak with over 19 thousand hectares in 2018 seem to generate higher benefit for farmers than mono- perennial crop ones (Provincial People's Committee of Dak Lak, 2018a).

Notwithstanding, the perennial crop production has faced challenges and vulnerabilities recently (i.e., irrigation systems, pests and diseases, investments) and the extreme weather (drought, heavy rains) and economic crisis (tang Ton \& Buu, 2011; Amarasinghe et al., 2015; Lebailly et al., 2015; Ward, Smith, \& Tran, 2016; Ho et al., 2018; Lan \& Nguyen, 2018; Nguyen \& Sarker, 2018; Provincial People's Committee of Dak Lak, 2018b). Meanwhile, farmers are in a lack of negotiating power in the supply chain resulting in their income limits. Since the 2000 s, the world coffee price dramatically dropped leading to a reduction of farmers' saving. Subsequently, farmers became serious in debts or repayments. And in some cases, the farmers have no ways to solve excepting selling their land (ICARD, 2002; Ha \& Shively, 2008). In response to these issues, farmers look for not only viable economic alternatives but also options to mitigate difficult scenarios (i.e., cost reduction, removal of other crops) to generate more profit.

The specific choices that were reported by previous studies include transferring of mono-culture to crop mix, converting to higher latitudes and elevations, switching to the crop calendar, cultivating perennial crops under shade trees, applying good agricultural productions and shifting from mono-crop system to synchronized or intercropping systems (Chau, 2007; Bosselmann et al., 2009; Sacks \& Kucharik, 2011; Park, 2012; Cho \& McCarl, 2017; Ho et al., 2017; Nguyen \& Sarker, 2018). Interestingly, empirical evidence exposed that intercropping systems such as coffee and pepper, coffee and avocado, coffee and banana could generate higher economic benefits than mono-culture (van Asten et al., 2015; Thi Duong Nga \& Thuy, 2017; Thuy et al., 2019). It means that an evaluation of mono-crop and intercropped farms is necessary to have a better understanding of economic performance as well as influential factors to the profitability.
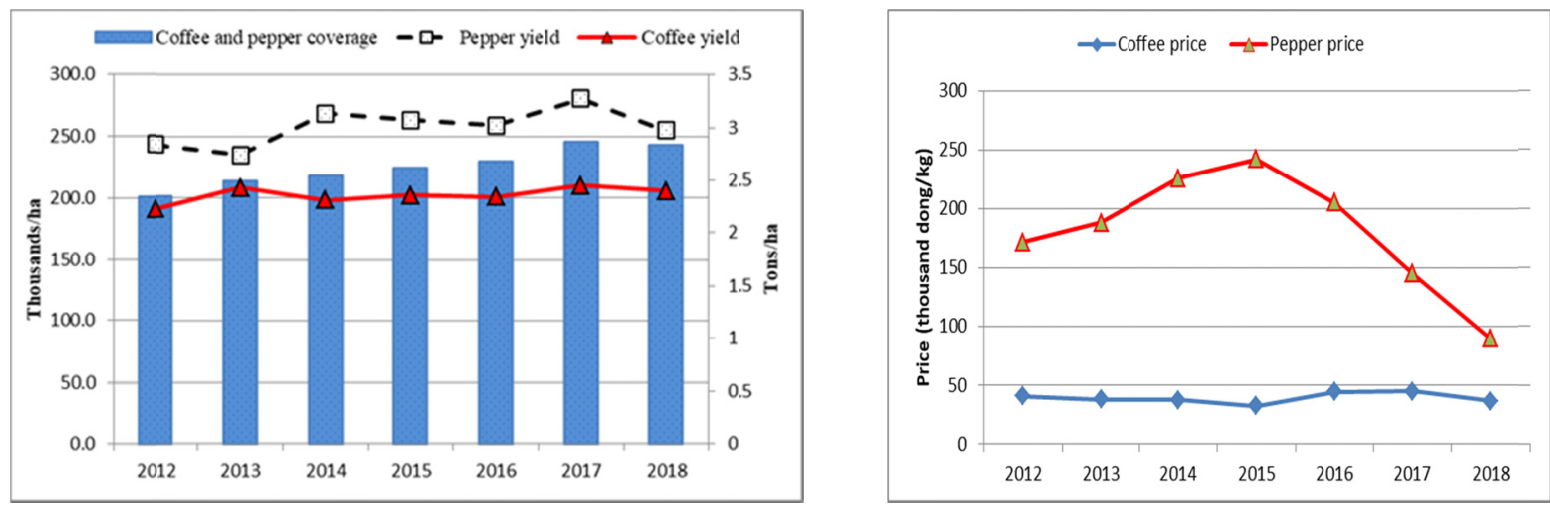

Figure 1. The production and market price of coffee and pepper in Dak Lak Province

Source: (DakLak DARD 2017; Provincial People's Committee of Dak Lak 2018a)

The study explores the profitable differentiation among perennial crop farms through two main objectives: (1) a comparison of economic efficiency of mono-crop farms and intercropped farms and (2) identifying factors affecting farmer's decision on adoption of the intercropped farm types. This research intends to give information to farmers in choosing the convenience of perennial crop farm types. Moreover, the results also provide economic evidence, factors usefully for local authorities in the sustainable development of perennial crops.

\section{Methods}

\subsection{Research Sites}

Dak Lak Province, Vietnam that is the largest perennial crop growing area in Central Highlands was chosen for the study. In this, Robusta coffee (tending to be easier to grow with higher yields and more resilient features) and black pepper are the two main commodities contributing a large part to the Dak Lak economic growth. Coffee was initially grown in 1920 s by the French accounting for $40 \%$ of Vietnam national coffee acreage. Also, the 
pepper growing area is standing the first position. Furthermore, three regions including Cu M'gar, Cukuin (the two largest regions among 13 Districts) and Buon Ma Thuot City are chosen for research sites, where are homogenous fertility (Figure 2). Besides mono-crop farms, the intercropped farms in these regions are also practiced.

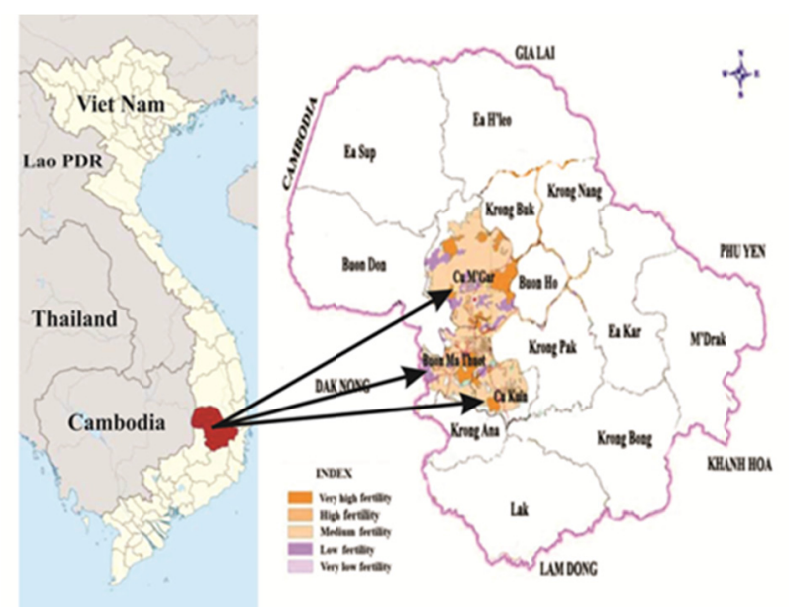

Figure 2. Map of Dak Lak province and research sites Source: (Author's own elaboration)

\subsection{Data Collection}

In this study, the secondary data was gathered from different sources such as yearly statistical books, Dak Lak Statistical Office: data from local authority at villages, districts and province.

- Data sources from focused groups, participatory assessment

Different activities were carried out as group discussions (three groups with 7 participants/group and other participatory activities were held to collect information related to coffee and pepper production generally in Dak Lak province.

\section{- $\quad$ Survey household}

This process was implemented, from January to April, 2019, to understand the annual production of coffee and pepper farms under two cultivation methods including mono and intercropped. Additionally, by reason of the average perennial crop farm size is approximately 1.5 hectares (cited by Head of Dak Lak People' Committee); surveyed farms were selected from 0.5 to 2 hectares to be convenient for studying.

According to (Diepart \& Allaverdian, 2018), there is no rule about the household sample size of the research sites. More than that, statistical units could have the same probability of being selected. For instance, if the sample rate is $10 \%$, meaning the sample size represents $10 \%$ of population (FAO, 2016). To obtain a representative sample, the study was conducted at three villages in three communes of three selected regions (Figure 2). The study collected $10 \%$ of villagers (selected households $(\mathrm{N})=0.1 \mathrm{n}$ ( $\mathrm{n}=$ populated size), who are cultivating coffee and pepper crops. In addition, the study was conducted to meet cost and time constraints. In overall, 86 households were interviewed using the face-to face with structured questionnaires which include household profile, input and output data, farm characteristics as following Table 1. In addition, 86 selected households were divided into two kinds of crops and two types of cultivated methods. Also, 120 plots were chosen in this research. Each household in research site owned over one plot of coffee and pepper relating to two approaches as mono and intercropped farms (Table 2).

Likewise, we assume that selected households will decide either to adopt the different intercropped farm types or to keep the present ones. With respect to intercropped farms, three options will be chosen including group 0 (Planters convert totally current crops to new perennial ones); group 1 (Planters intercrop fruit trees (durian and avocado) into the current plantation); group 2 (Planters shift current crops to new perennial ones and intercrop fruit trees).

This examines the factors affecting the adoption of different intercropped approaches by households. As reported by some previous studies(Tu et al., 2018; von Ketteler, 2018) based on these factors as determinants comprising (1) physical factors (crop profiles); (2) socio-personal factors (households' characteristics); (3) and economic factors, the specific variables of cultivating perennial crops in intercropped farms are displayed in Table 3. Firstly, crop profiles like pests and diseases and age of trees were relevant factors. For instance, diseases and pests 
accounted for $65 \%$ in making decisions (von Ketteler, 2018). Secondly, many previous reports mentioned households' characteristics affected farmers' adoption. Not only training status influenced the applying new technology but also farmers' decision and farm management were revealed (Kilpatrick, 2000; Chi \& Yamada, 2002). Thirdly, income was argued to associate with the adoption of on-farms and off-farms (Arellanes \& Lee, 2003; Adeola, 2010; Okuthe, 2014). Moreover, (Thuy et al., 2019) demonstrated that economic status (profits) affected households' decision on shifting their cropping systems.

Table 1. The explanation of sampling

\begin{tabular}{cccccc}
\hline Region & Commune & Village & (n) Populated size & Selected households $(\mathrm{N}=10 \% * n)$ & Intercropped adopter \\
\hline BMT & EaKao & Cao Thanh & 300 & 30 & 26 \\
CuMgar & Cu Suê & Tu & 310 & 31 & 27 \\
Cu Kuin & EaKtur & Muoi & 250 & 25 & 24 \\
\multicolumn{2}{c}{ Total of households } & & $\mathbf{8 6}$ & $\mathbf{7 9}$ \\
\hline
\end{tabular}

${ }^{\mathrm{a}}$ Number of villagers was reported by head of village

Table 2. The distribution of samples

\begin{tabular}{cc}
\hline Type of farm cultivation & Plots \\
\hline Mono coffee farms (MCFs) & 32 \\
Intercropped coffee farms (ICFs) & 30 \\
Mono pepper farms (MPFs) & 28 \\
Intercropped pepper farms (IPFs) & 30 \\
Total of plot samples & $\mathbf{1 2 0}$ \\
\hline
\end{tabular}

\subsection{Data Analysis}

- Measure the economic performance

In order to capture the profitability of farm approaches of perennial crops, an economic analysis evaluates the differential of economic viability, such as output, input cost, net farm income and profit indicators, of coffee and pepper farms among two cultivated methods (Barral et al., 2012; Hill \& Bradley, 2015; FAO, 2016; Spicka et al., 2019). Additionally, a Mann-Whiney U-test was applied to test whether there is a significant difference in the non-parametrical distribution of two groups (Ngọc, 2008; Statistic Solution, 2013).

- Econometric analysis

A multinomial logistic regression (multinomial regression-MR) is an extension of binary logistic regression to analyze the farmers' decisions across more than two categories in the dependent variables (Y). Hence, the MR permits to determine the occurrence probabilities of an event defined by Y. To do this, the reference category must be identified.

In this study, a multinomial logistic regression (multinomial regression-MR) that allows an analysis of the farmers' decisions across more than two categories in the dependent variables $(\mathrm{Y})$ is an extension of binary logistic regression. The MR permits to determine the occurrence probabilities of an event defined by Y. Particularly, Y is the farmers' decisions on three adoptions of intercropped farms. On the other side, MR examines whether which factors are affecting farmers' adoption relating to a variety of farm approaches.

$\mathrm{Y}$ was divided into three categories $\left(\mathrm{Y}_{0}, \mathrm{Y}_{1}, \mathrm{Y}_{2}\right)$ as following three groups with 0 as the reference category (Czepiel, 2002; Sarma \& Simpson 2007; Ojo et al., 2013; Dobson, 2019).

0 : Adopter intended to maintain current plantation and intercropped new fruit tree

$\mathrm{Y}_{\mathrm{i}}$ including 1: Adopter intended to convert plantations to new perennial crops

2: Adopter intended to shift plantation to new perennial crops and new fruit tree

The general expression of the logistic is as follows:

$$
\mathrm{Z}_{\mathrm{ij}}=\log \frac{P i}{P j}==\alpha_{\mathrm{ij}}+\beta_{\mathrm{ij}} \mathrm{X}_{1}+\beta_{\mathrm{ij}} \mathrm{X}_{2}+\beta_{\mathrm{ij}} \mathrm{X}_{3}+\ldots . .+\varepsilon_{\mathrm{ij}}
$$

Where $Z_{\mathrm{i} 0}=0$, therefore, $e^{Z i 0}=1$

Where: $\mathrm{P}_{\mathrm{i} 0}=\frac{1}{1+e^{Z i 1}+e^{Z i 2}}$ is the probability of occurrence for new perennial crops farms (Group 0 ) 
$\mathrm{P}_{\mathrm{i} 1}=\frac{e^{Z i 1}}{1+e^{Z i 1}+e^{Z i 2}}$ is the probability of occurrence for old plantation and fruit trees farms (Group 1)

$\mathrm{P}_{\mathrm{i} 2} \frac{e^{Z i 2}}{1+e^{Z i 1}+e^{Z i 2}} \quad$ is the probability of occurrence for new perennial crops and fruit trees farms (Group 2)

The independent variables in the MR are defined:

Table 3. Explaining Variables

\begin{tabular}{cc}
\hline Variables & Definitions \\
\hline Profit & Net return of farms after division of family labor cost \\
Other income & 1 if respondent has other income sources, 0 otherwise \\
Aging tree stock & 1 if plantation has over 20 years, 0 otherwise \\
Pests and diseases status & 1 if farm experienced pest and diseases, 0 otherwise \\
Training courses & 1 if farmer participated a training program, 0 otherwise \\
\hline
\end{tabular}

\section{Results and Discussion}

\subsection{Characteristics of Coffee and Pepper Farm Approaches}

Table 4 . The profiles of coffee and pepper farms

\begin{tabular}{lcccc}
\hline \multicolumn{1}{c}{ Items } & MCFs (N=32) & ICFs (N=30) & MPFs (N=28) & IPFs (N=30) \\
\hline 1. Average farm area (ha) & 1.1 & 1.0 & 0.8 & 1.0 \\
2. Density (trees/ha) & 1092 & 830 & 1163 & 900 \\
3. Age of trees (years) & 18 & 14 & 8 & 7 \\
4. Yield (ton/ha) & 2.0 & 1.9 & 2.15 & 1.7 \\
5. Average crop losses (trees/ha) & 28 & 21 & 32 & 23 \\
\hline
\end{tabular}

Source: Surveyed data, 2019

In this section, the study reveals general information of coffee and pepper farms' profiles by distinguishing farm types in research sites. In sizes, apart from the mono-pepper farms in residential gardens (Thuy et al., 2019), the others were similar around one-hectare acreage. Furthermore, the MCFs and MPFs had a higher number of trees with crowdedness at 1092 coffee and 1163 pepper trees per hectare. On the other hand, a density of coffee and pepper in intercropped farms were at 830 and 900 trees, respectively. Besides, these crops were also compared among farm types in the research sites (see Appendix). It implies that the densities of MCFs and MPFs were lower than as advised by technical services (i.e., 1100 coffee and 1600 pepper trees whilst under 600 pepper ones in pepper intercropped farms were higher than recommendation (MARD, 2017, 2018). This is explained by a high density and excessive fertilizer misuse resulting in nutrition and soil imbalances, pest and disease infection and aging tree stock, a regular drop of crops (Scherr et al., 2015). Essentially, the number of crop losses for intercropped farms seems to be lower than that of mono-crop plots, marking up 28 coffee and 32 pepper trees per hectare. Correspondingly, farmers have a trend to replace or rejuvenated crops. However, they had no motivation for replanting when prices of coffee and pepper went down. For example, in 2018, the pepper price decreased significantly by 50\% as compared to mid-2016 (Lan \& Nguyen, 2018). In some cases, farmers admitted that although they tried to change died crops by new ones, it was problematic for growing later. On the other hand, the yields of MCFs and MPFs were higher than those of intercropped plots, at 2.0 tons of coffee and 2.15 tons of pepper (Table 4).

\subsection{An Analysis of Economic Efficiency in Coffee and Pepper Farms}

\section{- The variable costs}

Because of coffee and pepper crops have a long life span, there is a closed relationship between annual costs and yields affecting crop efficiency for a long time. As a result, an analysis of variable cost components is a need detailed in Table 5.

Generally, intercropped farms were fewer than mono-crop farms regarding total expenses.

In coffee farms, MCFs had higher input costs (30.5 million) than ICFs (24.3 million VND per ha) including intermediate costs, labor costs, interest and depreciation expenses.

Concerning intermediate costs (IC), this cost was 22.6 million for MCFs and 12.8 million VND per ha for ICFs (Table 5). Other specific costs including chemical fertilizers, pesticides and herbicides, and watering were cut 
down at $54 \%, 36 \%$, and $21 \%$, respectively in ICFs as compared to MCFs. This is explained that the intercropped approaches (as coffee was grown under shade trees) preserve soil fertility from leaf litter and pruning which decreasing costs such as herbicide costs (over $40 \%$ of surveyed farmers handled herbicides) or labor costs for cutting grass or fertilizer or irrigation. As reported by previous authors, the pruning from the shade trees was used as green manure or mulch to taper off weeding area and fertilizers. In addition, increased shade-grown coffee area instead of growing coffee under full sun took off weight irrigation round per year (i.e., 650 liters/plant/round in three rounds per year was advised by MARD and only $25 \%$ of the potential crop evapotranspiration were provided by rainfall) and maintained high crop yield (Godoy \& Bennett, 1991; Albertin \& Nair, 2004; Cheesman \& Bennett, 2005; Bote \& Struik, 2011; Romyen, Sausue, \& Charenjiratragul, 2018). Interestingly, when the coffee sector has faced enormous challenges, especially excessive fertilizer and irrigation caused soil acidification, infectious diseases, ICFs are a perfect and sustainable choice for farmers. In cases coffee is the main crop in Dak Lak province, authors suggested that local government should encourage coffee crop practice by intercropping with other crops such as pepper, cocoa. This is consistent with (Scherr et al., 2015) that mono-cropping was associated with high water demand, evapotranspiration rate.

Table 5. Distribution of production costs between mono-crop farms and intercropped farms. Unit: Thousand VND per ha

\begin{tabular}{|c|c|c|c|c|c|c|c|c|c|c|}
\hline \multirow{2}{*}{ Indicators } & \multicolumn{2}{|c|}{ MCFs $(\mathrm{N}=32)$} & \multicolumn{2}{|c|}{ ICFs $(\mathrm{N}=30)$} & \multirow{2}{*}{ Sig } & \multicolumn{2}{|c|}{ MPFs $(\mathrm{N}=28)$} & \multicolumn{2}{|c|}{ IPFs $(\mathrm{N}=30)$} & \multirow{2}{*}{ Sig } \\
\hline & Mean & SD & Mean & SD & & Mean & SD & Mean & SD & \\
\hline Input costs & 30.5 & 9.6 & 24.3 & 8.1 & $0.00^{*}$ & 50.0 & 25.0 & 28.0 & 10.0 & $0.00^{*}$ \\
\hline I. IC & 22.6 & 8.9 & 12.8 & 4.7 & $0.00^{*}$ & 30.3 & 19.6 & 15.0 & 6.5 & $0.00^{*}$ \\
\hline Fertilizer & 18.4 & 7.7 & 10.0 & 4.3 & $0.00^{*}$ & 18.2 & 10.4 & 10.8 & 4.4 & $0.00^{*}$ \\
\hline Manure & 3.8 & 4.7 & 2.5 & 3.6 & NS & 5.7 & 5.8 & 3.2 & 3.4 & NS \\
\hline Chemical & 14.6 & 6.7 & 7.5 & 3.0 & $0.00^{*}$ & 12.5 & 7.0 & 7.5 & 2.7 & $0.00^{*}$ \\
\hline 2. Pesticides, herbicides & 1.9 & 1.8 & 1.2 & 0.8 & NS & 9.6 & 11.4 & 2.8 & 2.9 & $0.01^{*}$ \\
\hline 3. Watering & 1.4 & 1.1 & 0.7 & 0.4 & $0.04^{* *}$ & 0.9 & 0.8 & 0.6 & 0.4 & NS \\
\hline 4. Transporting & 0.3 & 0.4 & 0.2 & 0.1 & NS & 0.3 & 0.3 & 0.1 & 0.1 & $0.03^{* *}$ \\
\hline 5. Packaging & 0.4 & 0.4 & 0.3 & 0.4 & $0.01^{*}$ & 0.3 & 0.3 & 0.2 & 0.3 & NS \\
\hline 6. Others & 0.2 & 0.3 & 0.4 & 0.6 & $0.01^{*}$ & 1.0 & 1.3 & 0.4 & 0.6 & $0.00^{*}$ \\
\hline II. Hired labor cost & 3.2 & 3.0 & 4.1 & 4.8 & $N S$ & 7.6 & 6.0 & 8.2 & 5.6 & $N S$ \\
\hline III. Interest cost & 2.7 & 3.6 & 0.3 & 0.4 & $0.00^{*}$ & 6.0 & 8.4 & 0.5 & 0.4 & $0.00^{*}$ \\
\hline IV. Depreciation & 2.0 & 1.3 & 2.0 & 1.8 & NS & 6.1 & 2.4 & 4.5 & 1.8 & $0.01^{*}$ \\
\hline
\end{tabular}

Source: Author's calculation. Excluding family labor cost.

Mann-Whitney U test. ${ }^{* * *}$ Significant at $1 \%$ and $5 \%$ level

Equivalently, to pepper farms, MPFs were higher expenses, where the annual cost amounted to 50 million and IC reached 30.3 million VND per ha, than those of IPFs (Table 5). Fortunately, as to IPFs, there was a rapid reduction rate in material expenditures including chemical fertilizers and pesticides-herbicides by $23 \%$ and $62.5 \%$ to compare with MPFs. This is explained similarly to ICFs. Also, IPFs were used by alive plant (i.e., $90 \%$ of surveyed intercropped farm types while this figure was $50 \%$ on MPFs). In earlier studies, pepper pillar as Cassia siamea and/or Leucaena leucocephala tree assisted not only micro-climate balance, heat, soil moisture and light, but also diminished pest and diseases infection (WASI and IAS, 2016).

The next component is labor costs of which mainly for hiring labor costs. Coffee and pepper production is labor intensity with over $50 \%$ of the total variable cost in Vietnam and $70 \%$ in Colombia (IDH, 2014; Thuy et al., 2019). From this, perennial crops urgently need more short time manual workers for picking fruits (i.e., a large number of laborers hired for picking ripe fruits on the optimum harvest time, from October to December for coffee and from February to April for pepper) (Hurri Sauli, 2015; NIAPP, 2017). In comparing to mono-crop, intercropped farms were considered to call for fewer laborers (including family members and hired laborers). The number of workers on MCFs and MPFs were 132 man-days and 220 man-days while these figures on intercropped farms were at 110 and 164 man-days per ha, respectively. The proof is that the intercropped plots that incurred fewer labors costs of irrigation and/or weeding had crowned trees than mono-crop plots. It means that intercropped farms are considered to decrease evaporation and weeding area. Besides, this is likely that the intercropped farms had less competition for off-farms activities encouraging farmers' participation in more other activities as a rural livelihood diversification.

In different circumstances, intercropped farms used more hired labor costs than mono-crop ones. For details, this 
cost for MCFs and MPFs achieved 3.2 and 7.6 million VND per ha while these figures were estimated at 4.1 and 8.2 million VND per ha for ICFs and IPFs, respectively (Table 5). The survey revealed that workers in intercropped farms are less powerful in securing the safety for the second crops than that of mono-crop ones. In other words, the mono-crop farms are more convenient than the others in production. To solve it, intercropped farmers should apply a reasonable density to improve the efficiency of labors instead of shortening the potential yields of the main crops (i.e., farmers can follow technical advice).

Undoubtedly, the IC depletion not only improves effectiveness but also seems to be appropriate for a sustainable orientation (low commodity prices) regarding the FAO guidelines for perennial crop farming and agricultural systems at small -scale producers (SAFA, 2013). Comprehensively, intercropped approaches seem to have lower costs than mono-crop ones. Significantly, in case of security fund, intercropped coffee approaches that helped to reduce by $23.7 \%$ of expenditures is likely to be the most applicable for rural households. Therefore, at the grass-root level, the author suggests that farmers should be interested in intercropped farm cultivation, especially coffee intercropped farms. As well, to enhance the second crop benefits like pepper, alive trees may be used for growing pepper instead of wooden and concrete pillars as well as following technical consultation. Additionally, farmers' perspective on the role of intercropped farms needs to be reinforced in the future. At the community level, empirical evidence should be publicized widely through practical activities such as workshops, talk shows and hands-on activities along with the current encouraging programs. So far, financial support needs to be administered perennial crop production with higher investments because the smallholders rarely have savings available was proved (Hurri Sauli, 2015).

\section{The economic viability of perennial crop farms}

The economic performance of mono-culture and intercropped plots is illustrated in Table 6 regarding gross output (GO), net farm income (NFI), profit, the ratio of GO to IC and the ratio of NFI to family labors.

On the subject of coffee farms, even if ICFs obtained less GO value at 68.2 million than MCFs at 70.2 million VND per ha, the other indicators including NFI and profit at 6.8 million (17\%) and 11.7 million (62\%), respectively were higher than MCFs (Table 6). Remarkably, the ratio of GO to IC for ICFs was not significant in comparison with that of MCFs. Pointedly, the ratio was 6.0 for ICFs (it means that an increase of 1 Viet Nam dong (VND) in IC leads to an increase of 6 VND per hectare in GO) while this proportion was only 3.4 for MCFs (Table 5). Obviously, in a severe situation like low coffee price, ICFs seem to be an alternative for farmers to spend fewer costs and more profitability. Thus, ICFs' farmers should apply a reasonable density for coffee plots and second crops. This aims to avoid the depletion of resource as well as create an efficient production.

Next, IPFs had higher deduction rates of GO and NFI at $22.5 \%$ and $5.7 \%$ than those of MPFs, respectively. The study showed that IPFs had a higher rate of return and the ratio of GO to IC than MPFs, increased by nearly $30 \%$ and $50 \%$. It was recommended that IPFs should use the alive plants as the pillars to diminish the initial capital (the start-up cost burden). Besides, these alive plants are used in intercropped farms to create employment opportunities for family members (Thuy et al., 2019). Among intercropped farms, IPFs that challenge the poor or small saving households are intensive crop production comparing to ICFs.

Table 6. The economic efficiency of mono and intercropped farms

\begin{tabular}{|c|c|c|c|c|c|c|c|c|c|c|}
\hline \multirow{2}{*}{ Items } & \multicolumn{2}{|c|}{ MCFs $(\mathrm{N}=32)$} & \multicolumn{2}{|c|}{ ICFs $(\mathrm{N}=30)$} & \multirow{2}{*}{ Sig } & \multicolumn{2}{|c|}{ MPFs $(\mathrm{N}=28)$} & \multicolumn{2}{|c|}{ IPFs $(\mathrm{N}=30)$} & \multirow{2}{*}{ Sig } \\
\hline & Mean & SD & Mean & SD & & Mean & SD & Mean & SD & \\
\hline 1. Gross output (Mil. VND/ha) & 70.2 & 31.3 & 68.2 & 22.7 & NS & 120.0 & 51.0 & 93.0 & 42.0 & $0.04^{* *}$ \\
\hline 2. Price (Mil. VND/ton) & 34.5 & & 34.5 & & NS & 56.0 & & 56.0 & & NS \\
\hline 3. Farm income (Mil. VND/ha) & 39.6 & 30.2 & 46.4 & 23.0 & NS & 70.0 & 55.0 & 66.0 & 41.0 & NS \\
\hline 4. Profit (Mil. VND/ha) & 18.8 & 29.7 & 30.5 & 21.6 & $0.05^{* *}$ & 35.0 & 62.0 & 44.0 & 40.0 & NS \\
\hline 5. $\mathrm{GO} / \mathrm{IC}$ & 3.4 & 1.7 & 6.0 & 3.0 & 0.04 & 8.6 & 4.8 & 15.5 & 10.0 & $0.03^{* *}$ \\
\hline 6. Family labor (man-days) & 115 & 27.5 & 88.0 & 23.5 & $0.00^{*}$ & 198.0 & 82.0 & 118.5 & 37.0 & $0.00^{*}$ \\
\hline 7. Return to family labor & 0.4 & 0.3 & 0.5 & 0.3 & $0.00^{*}$ & 0.5 & 0.7 & 0.6 & 0.4 & NS \\
\hline
\end{tabular}

Source: Author's calculation.

Mann-Whitney U test. ${ }^{* * *}$ Significant at $1 \%$ and $5 \%$ level

To conclude, the analysis reveals that intercropped farms are an alternative in perennial crop production whereas lower variable costs and higher return rates as observed to mono-crop approaches. This is associated with previous studies that mono-cropping was lower farm income than diversified cropping (Scherr et al., 2015; Thuy et al., 2019). 
Notably, as Dak Lak Province experienced a significant complication about irrigation for coffee and other industrial crops through drought and prices crisis, intercropped farms have been likely more convenient, especially ICFs. The authors recommend that farmers and local authorities should pay more attention to the economic performance of intercropped farms, especially in coffee farms. However, many farmers perceived that they could maximize their earnings via mono-culture without shade trees. As a result, training programs that help to changes farmers' awareness should be noticed for the coming years.

\subsection{Factors Affecting Farmers' Decision on Practice of Intercropped Farms}

This paper used multinomial logistic regression to examine the factors based on three components including crop profile, households' characteristics and economic criteria to impact on farmers' adoption of the intercropped farm approaches. The different types of farmers' decision categorize three groups; ((Group 0: farmers maintain current plantation and intercropped new fruit tree); (group 1: farmers convert to new intercropped farm); (farmers replace new intercropped farm and new fruit tree)), Table 7 shows the number of respondents preferring the farm approaches.

Table 7. Factors influencing the adoption of different intercropped farm types

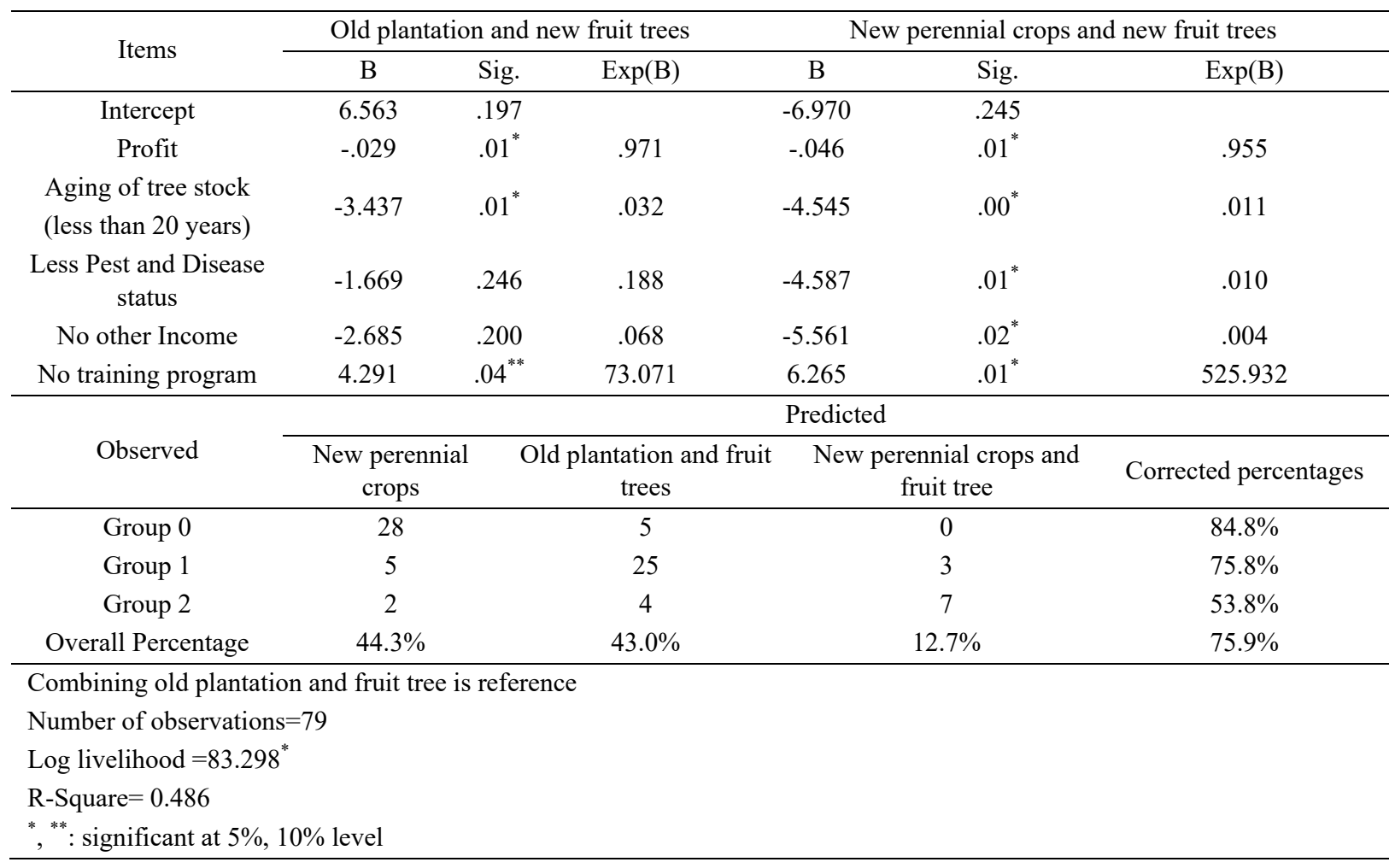

Table 7 shows that the value of the likelihood ratio is 83.298 , reaching $1 \%$ significance of probability level. As well, the pseudo R2 value of 0.48 confirms that the explanatory variables are significant in explaining farmers' choice by type of intercropped farms and the correctness of the associated logistics. The result of the multinomial logistic regression declared that there was the relationship between factors and the farmers' decisions on adopting a type of intercropped farms as illustrated by the coefficients of the model (B). On the other side, MR analysis confirmed that the factors explaining farmer's choice of adopting intercropped farm types include farm profiles (pest and disease status; age of trees), farmers' characteristics (training) and economic factors (profits and other income) were a connection with (von Ketteler, 2018). Furthermore, the prediction for group 0 was the highest percentage with $84.8 \%$ while groups 1 and 2 were $75.8 \%$ and $53.8 \%$, respectively. Overall, MR revealed that the prediction of this model reached $76 \%$ (Table 7). This demonstrated that perennial intercropping is more interesting than the others.

Individually, a comparison between group 1 and conference group: Profits and age of trees were negative significance to intend adoption from reference group to group. Meanwhile, no trainers were a positive influence. It implies that the profits and age of plantations (less than 20 years) are raised, the farmers' probability into converted into new intercropped farms reduced as compared to the decision of group 1. For instance, B (profits and age of trees) are -0.29 and -3.437 , therefore, $\log$ (odds) decreases 0.29 and 3.437 units when profits and age 
of trees expand one unit, respectively.

Similarly, a connection between group 2 and conference group (0): Profits, trees age less than 20 years, fewer pest and disease status and other income had unfavorable meaning on adoption from group 0 to group 2 while no trainers had a positive significance. It means that lows profit and high age of farms, high pest and disease infection and other income contribute an increase of probability in applying new plantation and new fruit trees. In as B (no trainer) is 6.265 , therefore, $\log$ (odds) increases 6.625 units when the number of untrained farmers steps up a unit (Table 7).

The findings are also consistent with previous studies such as (Lindskog et al., 2005; Hurri Sauli, 2015). More detailed, in terms of pests, diseases and aging tree stock, they caused low yields as well as high material costs for farmers affecting sustainable livelihoods in the future. For example, aging tree stock significantly deteriorates the yields making the farmers to chop down coffee plantations to convert into more profitable cash crops. According to (Thuy et al., 2019) the number of plantations captured dying crops due to the aging of trees, pests and diseases at $41 \%$ in Dak Lak Province. Besides, the total pepper area died in Central Highlands in 2018 reached 10 thousand ha (11.4\%) (Oanh, 2019). According to the (Provincial People's Committee of Dak Lak, 2018a) a coffee area around 42 thousand ha needs a rejuvenation due to aging tree stock. In the upcoming years, researches suggested that a reduction of pests and infectious diseases should be developed by the government.

Furthermore, untrained farmers have the positive influence to convert from the current plantation to group 1 and 2.. This is logical that untrained households were limited in the adoption of new farming, even applying the technologies. In some cases, they seem to have no information about the new farm approaches. In perennial crop production, to solve difficulties and maintain the profit, applying new technology (as irrigation, fertilizer) and taking care plantation plays an important role in sustainable development. However, a lack of technical training and meeting affected changes in technique. That's a reason why no trainers adopt new plantation instead of maintaining their current farms. This is in line with (Chi \& Yamada, 2002).

Finally, farmers are expected to be more interested in the adoption of other intercropped types as diversified farms to strengthen resilience. Nonetheless, converting progress needs to be analyzed carefully because perennial crop replanting is not only a call for long term investment but also a reduction in farmers' income during the early maturing period.

At governmental agencies, financial supports such as social banks, organizations and so on for rural households should be offered. Further, to diminish influences of these factors, households risk managements in perennial crop production such as preventing the pest and infectious diseases, enhancing the profitability need to be improved in the future.

\section{Conclusion}

To be concluded, perennial crop production subsidizes a large part on economic development at national and provincial levels. Another one is that there is a great consensus on analyzing the economic performance of different perennial crop farm types.

The study examines the economic efficiency among differentials of perennial crop farms via economic indicators as well as determinants impacting on the probabilities of adopting variety intercropped farm types

The finding pointed out that intercropped farms (ICFs and IPFs) were considered to use lower costs than mono-crop farms (MCFs and MPFs). Its reduction rate had $20.3 \%$ for ICFs and $44 \%$ for IPFs, in which IC fell dramatically, by $43 \%$ and $40 \%$, respectively comparing with MCFs and MPFs.

Regarding economic performance, ICFs and IPFs had higher profitability (an increase of $62.2 \%$ and 25.7\%) than those of MCFs and MPFs. Moreover, five factors include profits, age of trees, other income, constraints (pests and disease status) and training programs influence the farmer's decision in intercropped farm types.

In the coming years, all concerns must be considered to have effective perennial crop farms. Furthermore, factors determined should be improved.

Due to a limitation of time and funds, the study was carried at small scale and just only evaluated the two perennial crops (coffee and pepper) in three regions of Dak Lak Province. Besides that, the social benefits of perennial crop farms as well as factors affecting farmers' decision such as farmer's perception; external factors (social-institutional supports) need to be examined for the upcoming years.

\section{Acknowledgments}

The authors are grateful to Vietnam International Education Development (VIED) for providing financial assistance to this study. Additionally, appreciation goes to staff members of WASI, Dak Lak DARD, and Dak 
Lak Peoples' Committee who help the author in the field trip.

Phillipe Lebailly is the supervisor. He provided instructions for the research design. Le Duc Niem is the co-supervisor in Vietnam. He contributed the methodology and comments to the paper revision. Ho Thi Minh Hop and Philippe Burny provided the comments for the methodology and revision of the paper. Phan Thi Thuy, a $\mathrm{Ph}$.D. student, contributed the questionnaire design, survey methods, and suggestions to research sample as well as writing and editing the manuscript. All the authors read and approved the final manuscript.

\section{References}

Adeola, R. G. (2010). Influence of socio-economic factors on the adoption of soil conservation measures in Ibadan/Ibarapa agricultural zone of Oyo State. Report and Opinion, 2(7), 42-47. Retrieved from http://www.sciencepub.net/report/report0207/06_3391report0207_42_47.pdf

Albertin, A., \& Nair, P. K. R. (2004). Farmers' perspectives on the role of shade trees in coffee production systems: An assessment from the Nicoya Peninsula, Costa Rica. Human ecology, 32(4), 443-463. https://doi.org/10.1023/B:HUEC.0000043515.84334.76

Amarasinghe, U. A. et al. (2015). Toward sustainable coffee production in Vietnam: More coffee with less water. Agricultural Systems, 136, 96-105. https://doi.org/10.1016/j.agsy.2015.02.008

Annette, J., \& Dobson, A. G. B. (Eds.) (2019). Chapter 14: Binary and Multinomial logistic regression models. In An introduction to generalized linear models (Chapman an, pp. 539-651). https://doi.org/10.1016/B978-0-12-811216-8.00014-8

Arellanes, P., \& Lee, D. R. (2003). The determinants of adoption of sustainable agriculture technologies: Evidence from the hillsides of Honduras. Retrieved from https://ideas.repec.org/p/ags/iaae03/25826.html

van Asten, P. J. A. et al. (2015). Coffee-Banana Intercropping: Implementation guidance for policymakers and investors. Retrieved from https://www.researchgate.net/publication/285493955_Coffee-Banana_Intercropp ing_Implementation_guidance_for_policymakers_and_investors

Barral, S. et al. (2012). Assessing smallholder farming. Diagnostic analysis of family-based agricultural systems in a small region. Retrieved from https://www.researchgate.net/publication/282297611_Assessing smallholder_farming_Diagnostic_analysis_of_family-based_agricultural_systems_in_a_small_region

Batello, C. et al. (2014). Perennial crops for food security. In FAO Expert Workshop on Perennial Crops for Food Security Rome (Italy) 28-30 Aug 2013. Retrieved from http://www.fao.org/3/a-i3495e.pdf

Bosselmann, A. S. et al. (2009). The influence of shade trees on coffee quality in small holder coffee agroforestry systems in Southern Colombia. Agriculture, Ecosystems \& Environment, 129(1-3), 253-260. Retrieved from https://link.springer.com/content/pdf/10.1023\%2FB\%3AHUEC.0000043515.84334.76.pdf

Bote, A. D., \& Struik, P. C. (2011). Effects of shade on growth, production and quality of coffee (Coffea arabica) in Ethiopia. Journal of Horticulture \& Forestry, 3(11), 336-341. Retrieved from http://edepot.wur.n1/192807

Chau, T. M. L. (2007). The relative sustainability of coffee and mixed farmining systems in DakLak Province, Vietnam (May 2007, p. 120). Retrieved from https://dlc.library.columbia.edu/catalog/ldpd:497638/byte streams/content/content?filename=Chau_T_M_Long_Thesis.pdf

Cheesman, J., \& Bennett, J. (2005). Managing Groundwater Access in the Central Highlands (Tay Nguyen), Viet Nam. Retrieved from https://crawford.anu.edu.au/people/academic/jeff-bennett/managing-groundwateraccess-central-highlands-tay-nguyen-viet-nam

Chi, T. T. N., \& Yamada, R. (2002). Factors affecting farmers' adoption of technologies in farming system: A case study in Omon district, Can Tho province, Mekong Delta. Omonrice, 10, 94-100. Retrieved from https://pdfs.semanticscholar.org/f62f/b7147568c61610d4ad6b6de48f14a73f6f83.pdf?_ga=2.137038512.182 5252548.1564645290-331571101.1559893676

Cho, S. J., \& McCarl, B. A. (2017). Climate change influences on crop mix shifts in the United States. Scientific reports. Nature Publishing Group, 7, p. 40845. Retrieved from https://www.nature.com/articles/srep40845

Cuong, N. V. (2009). Measuring the impact of cash crops on household expenditure and poverty in rural Vietnam. Asia-Pacific Development Journal, 16(2), 87-112. https://doi.org/10.18356/e04e983e-en

Czepiel, S. A. (2002). Maximum likelihood estimation of logistic regression models: Theory and implementation. Available at czep. net/stat/mlelr. pdf. Retrieved from https://pdfs.semanticscholar.org/fd70/35ab3fca912c1f7 7c34ff0c4435d41ebd0d3.pdf?.ga=2.198250415.1825252548.1564645290-331571101.1559893676 
Dak Lak, SO. (2018). Dak Lak Statistical Yearbook 2018. SO. Buon Ma Thuot: Statistical Publishing House.

DakLak DARD. (2017). DakLaks'sustainable coffee plan till 2020 and Vision 2030. Retrieved from https://drive.google.com/file/d/1RteL7em-qZ26XPILLL_m68yfEgZq0XE5/view

Diepart, J. C., \& Allaverdian, C. (2018). Farming Systems Analysis: A guidebook for researchers and development practitioners in Myanmar. GRET. Retrieved from https://www.gret.org/publication/farmingsystems-analysis-guidebook-myanmar/?lang=en

Dinnes, D. L. et al. (2002). Nitrogen management strategies to reduce nitrate leaching in tile-drained Midwestern soils. Agronomy Journal, 94(1), 153-171. https://doi.org/10.2134/agronj2002.0153

Dixon and Dennis. (2014). Perennial Crops and Trees: Targeting the Opportunities Within a Farming Systems Context. In Perennial crops for food security (p. 17). Retrieved from https://landinstitute.org/wp-content/ uploads/2014/11/PF_FAO14_ch23.pdf

Entz, M. H. et al. (2002). Potential of forages to diversify cropping systems in the Northern Great Plains. Agronomy Journal, 94(2), 240-250. https://doi.org/10.2134/agronj2002.0240

FAO. (2016) Agricultural Cost of Production Statistics Guidelines for Data Collection, Compilation and. FAO, Rome. Retrieved from http:/gsars.org/wp-content/uploads/2016/02/Handbook-on-Agricultural-Cost-ofProduction-Statistics-28-02-2016.pdf

Godfray, H. C. J. et al. (2010). Food security: The challenge of feeding 9 billion people. Science, 327(5967), 812-818. https://doi.org/10.1126/science. 1185383

Godoy, R., \& Bennett, C. P. A. (1991). The economics of monocropping and intercropping by smallholders: The case of coconuts in Indonesia. Human Ecology, 19(1), 83-98. https://doi.org/10.1007/BF00888978.

GSO. (2018). Results of the rural, agricultural and fishery census 2016. Statistical publishing house.

GSO. (2019). Agriculture, hunting, forestry and fishing (pp. 339-425). https://doi.org/10.18356/f3ba966d-en-fr

Ha, D. T., \& Shively, G. (2008). Coffee boom, coffee bust and smallholder response in Vietnam's Central $\begin{array}{lllll}\text { Highlands. Review of Development } & \text { Economics, }\end{array}$ https://doi.org/10.1111/j.1467-9361.2007.00391.x

Hill, B., \& Bradley, B. D. (2015). Comparison of farmers' incomes in the EU member states. Report for European Parliament, Komisja Europejska, DG Internal Policies, Raport dla Parlamentu Europejskiego, Bruksela. Retrieved from http://www.europarl.europa.eu/RegData/etudes/STUD/2015/540374/IPOL_STU (2015)540374_EN.pdf

Ho, T. Q. et al. (2017). Which farming systems are efficient for Vietnamese coffee farmers? Economic Analysis and Policy, 56, 114-125. https://doi.org/10.1016/j.eap.2017.09.002

Ho, T. Q. et al. (2018). Eco-efficiency analysis of sustainability-certified coffee production in Vietnam. Journal of cleaner production, 183, 251-260. https://doi.org/10.1016/j.jclepro.2018.02.147

Hurri Sauli, et al. (2015). Report Rural Finance of Coffee Smallholders in Vietnam - Case Study in Dak Nong Province. Retrieved from https://asia.ifad.org/documents/10751/084b3711-14d8-42f8-8d40-d604fa93e385

ICARD, O. (2002). The Impact of the Global Coffee Trade on Dak Lak Province, Viet Nam: Analysis and Policy Recommendations. ICARD: Hanoi. Retrieved from http://hdl.handle.net/10919/65831

IDH. (2014). A business case for sustainable coffee production in Colombia. Retrieved from http://www.snv.org/project/sustainable-coffee-programme

von Ketteler, L. (2018). Factors influencing farmer's decision-making and resilience: The case of banana production in Amubri, Costa Rica. Retrieved from https://pdfs.semanticscholar.org/fa6d/f2c59bf8f85a10fe6 0e69c1e881eb34738c0.pdf

Kilpatrick, S. (2000). Education and training: Impacts on farm management practice. The journal of agricultural education and extension, 7(2), 105-116. https://doi.org/10.1080/13892240008438811

Lan, Q., \& Nguyen, T. (2018). The struggling of pepper, Customesnews. Retrieved from https://customsnews.vn/the-struggling-price-of-pepper-6528.html

Lebailly, P. et al. (2015). Développement rural et petite paysannerie en Asie du Sud-Est: Leçons d'expériences au Vietnam et au Cambodge. L'Harmattan.

Lindskog, E. et al. (2005). When Rapid Changes in Environmental, Social and Economic Conditions Converge : 
Challenges to Sustainable Livelihoods in Dak Lak, Vietnam. Retrieved from https://mediamanager.sei.org/documents/Publications/Risk-livelihoods/SEI_Lindskog_Dak_Lak_2005.pdf

MARD. (2017). Coffee, pepepr planting technology.

MARD. (2018). Intercropping of perennial crop technology (p. 2).

Ngọc, H. T.-C. N. M. (2008). Phân tích dữ liệu nghiên cứu với SPSS (Analysis data for research with SPSS). Nhà xuất bản Hồng Đức.

Nguyen, G. N. T., \& Sarker, T. (2018). Sustainable coffee supply chain management: a case study in Buon Me Thuot City, Daklak, Vietnam. International Journal of Corporate Social Responsibility, 3(1), 1. https://doi.org/10.1186/s40991-017-0024-X

Nguyen, T. H. (2017). An Overview of Agricultural Pollution in Vietnam: The Crops Sector. World Bank. Retrieved from http://documents.worldbank.org/curated/en/681201516788003445/pdf/122934-WP-PUBLI C-Vietnam-crops-VNM.pdf

NIAPP. (2017). Viet Nam pepper industry development planning to 2020, and vision 2030. Retrieved from http:/www.niapp.org.vn/info/en/dtcl/giaidoan4/viet-nam-pepper-industry-development-planning-to-2020-a nd-vision-2030/54161

Oanh, D. T. (2019). Thực trạng sản xuất hồ tiêu tại Tây Nguyên, Vietnam (The sistuation of pepper production in Central Highlands). Buon ma thuot. Retrieved from http://wasi.org.vn/doi-net-ve-thuc-trang-san-xuatho-tieu-tai-tay-nguyen-hien-nay/

Ojo, M. A. et al. (2013). Multinomial logit analysis of factors affecting the choice of enterprise among small-holder yam and cassava farmers in Niger State, Nigeria. Journal of Agricultural Sciences, 4(1), 7-12. https://doi.org/10.1080/09766898.2013.11884695

Okuthe, I. K. (2014). The influence of institutional factors on the adoption of integrated natural resource management technologies by small scale farmers in South Western Kenya. Asian Journal of Agricultural Sciences, 6(1), 16-32. Retrieved from https://pdfs.semanticscholar.org/3704/6e25c66937ac4218df017caf 2f22884b2344.pdf

Park, J. (2012). Essays on Impacts of Climate Change on Agricultural Sector in the US. Texas A \& M University. https://doi.org/10.1007/BF00140510

Pimentel, D. (1987). World agriculture and soil erosion. BioScience, 37(4), $277-283$. https://doi.org/10.2307/1310591

Provincial People's Committee of Dak Lak. (2018a). Coffee annual report 2017-2018. Retrieved from https://daklak.gov.vn/documents/10181/872901/293.pdf

Provincial People's Committee of Dak Lak. (2018b). The overview of Dak Lak province. Retrieved from http://www.smfederation.org.sg/sites/default/files/smf/content/internationalization/Overview_of_Dak_Lak_ Province.pdf

Romyen, A., Sausue, P., \& Charenjiratragul, S. (2018). Investigation of rubber-based intercropping system in Southern Thailand. Kasetsart Journal of Social Sciences, 39(1), $135-142$. https://doi.org/10.1016/j.kjss.2017.12.002

Sacks, W. J., \& Kucharik, C. J. (2011). Crop management and phenology trends in the US Corn Belt: Impacts on yields, evapotranspiration and energy balance. Agricultural and Forest Meteorology, 151(7), 882-894. https://doi.org/10.1016/j.agrformet.2011.02.010

SAFA, F. A. O. (2013). Sustainability Assessment of Food and Agriculture systems. FAO, Rome. Retrieved from http://www.fao.org/3/a-at110e.pdf

Sarma, S., \& Simpson, W. (2007). A panel multinomial logit analysis of elderly living arrangements: Evidence from aging in Manitoba longitudinal data, Canada. Social Science \& Medicine, 65(12), 2539-2552. https://doi.org/10.1016/j.socscimed.2007.07.012

Scherr, S. J. et al. (2015). Steps toward green: Policy responses to the environmental footprint of commodity agriculture in East and Southeast Asia. EcoAgriculture Partners. Retrieved from https://www.researchgate. net/publication/282768221_Steps_Toward_Green_Policy_Responses_to_the_Environmental_Footprint_of_ Commodity_Agriculture_in_East_and_Southeast_Asia

Spicka, J. et al. (2019). Approaches to estimation the farm-level economic viability and sustainability in 
agriculture: A literature review. Agricultural Economics. doi: 10.17221/269/2018-AGRICECON

Statistic Solution. (2013). Statistical analysis. Retrieved from http://www.statisticssolutions.com/directory-ofstatistical-analyses/

tang Ton, N., \& Buu, B. C. (2011). How to Prevent the Most Serious Diseases of Black Pepper (Piper Nigrum 1.)-A Case Study of Vietnam. In PC Annual Meeting in Lombok, Indonesia. Retrieved from http://www.ipcnet.org/admin/data/ses/1329362855thumb.pdf

Thang, P. D. (2018). Pepper value chain in Dak Lak and Dak Nong.

Thi Duong Nga, N., \& Thuy, P. T. (2017). Economic performance of coffee and pepper intercropping in Quang Hiep commune, Cumgar district, Dak Lak province. Vietnam J. Agri.Sci., 15(9), 1277-1287. Retrieved from https://orbi.uliege.be/bitstream/2268/235821/1/Economicperformanceofcoffee and pepper intercropping.pdf

Thuy, P. et al. (2019). Economic Analysis of Perennial Crop Systems in Dak Lak Province, Vietnam. Sustainability, 11(1), 81. https://doi.org/2071-1050/11/1/81

Tranmer, M., \& Elliot, M. (2008). Binary logistic regression. Cathie Marsh for census and survey research, paper, p. 20.

Tu, V. H. et al. (2018). Modelling the factors affecting the adoption of eco-friendly rice production in the Vietnamese Mekong Delta. Cogent Food \& Agriculture, 4(1), p. 1432538. https://doi.org/10.1080/23311932.2018.1432538

Ward, M., Smith, G., \& Tran, Q. (2016). This Report Contains Assessments of Commodity and Trade Issues Made by Usda Staff and Not Necessarily Statements of Official US Government Policy. USDA Foreign Agricultural Service: Washington, DC, USA, p. 11. Retrieved from https://gain.fas.usda.gov/Recent GAIN Publications/Rice Price - Weekly_Bangkok_Thailand_2-5-2019.pdf

WASI and IAS. (2016). Results about pepper pillar in Vietnam. BMT city. Retrieved from $\mathrm{http} / / /$ iasvn.org/chuyen-muc/Ket-qua-nghien-cuu-ve-cay-tru-tieu-8289.html

World Bank. (2016). Transforming Vietnamese Agriculture: Gaining More from Less (N. P. Mai, Ed.). Retrieved from http://documents.worldbank.org/curated/en/116761474894023632/pdf/108510-WP-PUBLIC.pdf

\section{Appendix}

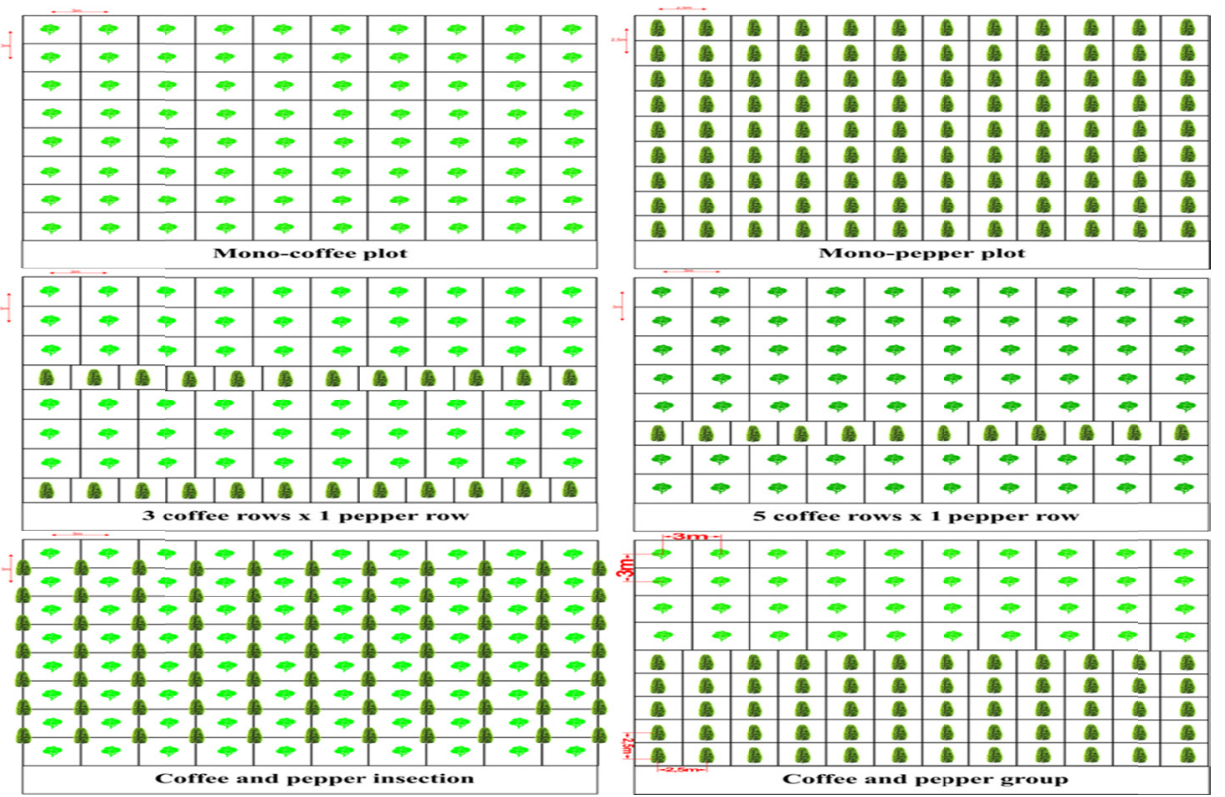

Figure 3. The space of coffee and pepper crops at different farm approaches

\section{Copyrights}

Copyright for this article is retained by the author(s), with first publication rights granted to the journal.

This is an open-access article distributed under the terms and conditions of the Creative Commons Attribution license (http://creativecommons.org/licenses/by/4.0/). 